\title{
Erratum
}

\section{Proteases As Catalytic Agents in Peptide Synthetic Chemistry: Shifting the Extent of Peptide Bond Synthesis from a "Quantité Negligeable" to a "Quantité Considérable"}

\author{
Willi Kullman
}

Please note that in Journal of Protein Chemistry, Vol. 4, No. 1, pp. 1-22, there is an error in the text.

On p. 7, Paragraph 3 should read as follows:

"Actually, the ionization behavior is also influenced by the hydrogen ion concentration of the reaction medium. However, any $\mathrm{pH}$ variation is a double-edged sword, because any favorable shift of the ionic equilibrium of one educt is accompanied by an unfavorable shift of the ionic equilibrium of the other educt."

\footnotetext{
${ }^{1}$ Max-Planck-Institut für Biophysikalische Chemie, Göttingen, West Germany. 